\title{
An Integrative Framework for Customizations on Satisfaction: The Case of an Online Jewelry Business in China
}

\author{
Vincent Cho' ${ }^{1}$, Candy Lau ${ }^{2}$ \\ ${ }^{1}$ Department of Management and Marketing, The Hong Kong Polytechnic University, Hong Kong, China \\ ${ }^{2}$ Cando Times Limited, Hong Kong, China \\ Email: Vincent.Cho@polyu.edu.hk
}

Received 25 November 2013; revised 23 December 2013; accepted 21 January 2014

Copyright @ 2014 by authors and Scientific Research Publishing Inc.

This work is licensed under the Creative Commons Attribution International License (CC BY). http://creativecommons.org/licenses/by/4.0/

c) (i) Open Access

\begin{abstract}
Upon the technological advancement of production flexibility, supply chain agility, and customer behavioral tracking, many online businesses now develop their customization strategies. In this regard, this study proposes an integrative framework for customization of product information, transaction handling, product attribute, and sales' service. We are interested in how these customizations affect customer satisfaction. From our web-based survey on a renowned online jewelry company in China, we collected 1383 responses from its customer database. Our findings showed that information, product and sales' service customizations have significant influence on customer satisfaction. Moreover, ordinary members as compared with VIP members feel more satisfied once they receive customized services.
\end{abstract}

\section{Keywords}

\section{Customization, Satisfaction, Online Business}

\section{Introduction}

With the technological advancement of production flexibility, supply chain agility, and customer behavioral tracking, many online businesses now develop their customization strategies. Early customization relies on customers' choosing product attributes to alter the default option and to create a unique product, which begins the era of mass customization (e.g. [1]-[3]). Coming along with sophisticated logistic and scheduling arrangement with suppliers and distributors in supply chain management, companies are capable to launch the "build to order" strategy (e.g. [4] [5]). Nowadays, customer relationship management enables companies to pay more attention to 
the preferences and needs of an individual customer, and to serve customers differently according to their importance and value (e.g. [6] [10]).

Integrating all the above developments together, companies are now in full swing towards customization. Reference [9] has classified customization into three domains: transaction customization, information customization and product customization. Our framework extends customization on the service domain and is founded by the process of merchant brokering involving the evaluation of a product based on its features, possible options in choosing product attributes, price, warranty, availability, delivery time, payment options, and sales' services [11]. We look into customization over four different aspects: 1) product and promotional information, 2) payment and logistic options, 3) product attribute options, and 4) service levels. The followings highlight their current developments.

Information customization-With the assistance from business intelligence and data mining tools, customer databases are analyzed to extract customer preferences. Customized information, which would arouse the interest of a customer towards some new products, is pushed to the customer according to his/her shopping behavior. For instance, Amazon.com pushes customized information of new books based on the past purchases of a customer. Once the data-miner identifies a match between the interest of a customer and the latest products of thousands of small retailers which are attached to their zShops section, Amazon.com will pass the related information to the customer via email.

Product customization-Customized products are co-created with customers via mixing and matching product components from a list of options [12]. Upon satisfying individual needs, co-created products are more valuable than traditional and standardized products [13] [14]. Furthermore, a company can understand consumers' preferences based on their selections [12] [15]. Along this vein, Dell.com has achieved great success with its configuration system for customized computers via its online platform. Land's End allows its customers to co-design their own jeans and clothes with different combinations of color, fabric, style, and size. Priceline offers travelers different options to tailor-make their itineraries.

Logistic customization-Close relationships with the suppliers and logistic partners facilitate a company to arrange the production and delivery of a product. This is related to the flexibility of a company in handling build-to-order production and allows a company to offer different payment and logistic options to its customers. In this regard, automobile companies such as Toyota manage their supply chains and utilize their production plants for agile production. Peapod customers can also specify the delivery according to their own preference.

Service customization-Nowadays, companies are no longer holding up the preferential treatment to their VIP customers, instead, customized service is being served for an individual customer based on their needs and preferences. This would help build up the customer satisfaction and loyalty. Friend Finder

(http://www.friendfinder.com), an online dating service, customizes its service levels ranging from self-serve to a customized service at different prices. To our knowledge, service customization has not been addressed much in the literature.

Compared with traditional business, customization in the online business depends much on the information technologies, which would be essential to provide customized information, to allow customers to specify their product, to offer customized payment and delivery arrangement, and to service the customers preferentially and differently. Moreover, competitions in online business are only a mouse click away from each other. Therefore, understanding customer satisfaction in an online store is critical and we hypothesize that customizations would be important for building up customer satisfaction. We also investigate if there are differences between two types of customers (ordinary and VIP members) on the theoretical predictions of our framework.

In order to testify our framework, we would like to select a business which pays much attention to customizing its products and services in order to fit the taste and preference of customers. Since customers are picky in selecting a luxury product, we select an online jewelry company in China for our data collection. According to [16], jewelry business is a kind of dynamic mass-market. Hence, mass service customization would be the right approach to dealing this business. In general, customers would be more impressed by the customizations in an online store selling luxury products than that in other online businesses on necessity products.

Today, most customers usually do not hesitate when they purchase inexpensive items online, such as books or clothes. This habit is migrating towards luxury products. For example, Blue Nile (www.bluenile.com), the most well-known US-based online jewelry retailer sold more engagement jewelry than Tiffany \& Co. This provides indisputable evidence that online jewelry business is now grabbing a considerable share of the market. In 2011, Blue Nile reported that its first-quarter net sales had increased 8.3\% quarter-on-quarter to US\$80.2M from NILE 
news in Nasdaq. These figures show that people are just as willing to pay for luxury-brand items from well-established US online markets as they are from retail shops.

While evidence from the US confirms the success of selling luxury products online, it is not clear how well the situation will translate into other cultural contexts, such as that of mainland China, in which the online jewelry business is still in the developmental phases. According to [17], there are similarities and differences between US and Taiwanese respondents in the acceptance of online apparel customization. China is a promising market for online businesses. By the end of 2010, the total number of "netizens" in China reached $457 \mathrm{M}$, representing $34.3 \%$ of the entire population and around one-third of the online market was related to diamond sales in 2011 from China Internet Network Information Center.

In particular, the law in China mandates that all diamonds and other types of jewelry be certified by the National Gemstone Testing Center (NGTC), the National Gold and Diamond Testing Center (NGDTC), or the Gemological Institute at the China University of Geosciences (GIC). NGTC and NGDTC are the foremost national-level authorities in diamond grading and jewelry certification in China, while GIC is the most respected independent authority on gemology, diamond grading, jewelry education, and certification and gemology research. Certification from these organizations is a key indicator of authentication and foundation of trust building among online jewelry businesses in China. Besides the brand name of the online jewelry store, consumers buying online jewelry in China rely on this rigorous certification process as relevant authorities will regularly police on the genuineness of those certificates. Nowadays, more consumers are buying their jewelries online than ever before, especially if they believe that they have found a reliable website. Moreover, testing our research model in the context of an online jewelry business will provide practitioners some helpful insight into customization strategies.

\section{Theoretical Framework}

Customization is defined as the tailoring of products and services to customers' individual needs. In the early studies, [18] suggested four approaches to customization: collaborative, adaptive, cosmetic and transparent. In the collaborative approach, companies customize products for customers based on different components and configurations of a product. The adaptive approach attempts to create a product which is customizable once it is in the hands of customers. For the cosmetic approach, standardized products are offered but with different options for their packaging. Using the transparent approach, a company designs its products based on the needs of their target customers. These approaches, which are not exclusive to each other, provide a framework for companies to determine their customization strategies. According to [19], customization is a continuum of strategies that depend on which parts of the manufacturing process lean toward standardization or its counter side-cusstomization. Nevertheless, the attitudes toward online mass customization are highlighted to be very important for intention to purchase and word of mouth [20].

In an online context with rich interactive media, customization covers a broader spectrum not exclusively limited to manufacturing process. Reference [21] proposed a buyer-centric strategy, which focuses to help customers identify their needs. Buyer-centric companies treat customers as active co-producers of products and servicesbeing offered via the Internet platform. An online company associated with buyer-centric strategy becomes an agent of the customer, 'renting' out to the customers pieces of its manufacturing, logistics, and other resources and allowing them to find, choose, design, and use what they need [21].

Those online buyer-centric companies need to address how they can collaborate with their customers in their manufacturing and business processes. As [22] suggested, the scope of customization requires companies to understand its underlying technology. Advanced databases and data-mining techniques allow online companies to analysis the behavior and preferences of their customers. As a result, customized information, products and services can be pushed to their customers in a cost-effective way. Furthermore, [23] identified five different types of customers using cluster analysis, which are namely as unfaithful, ordinary, experientialists, purposive and loyal experts, based on the four dimensions of online customer heterogeneity: value, knowledge, orientation and relationship. They proposed that an online company should treat customers differently according to their types.

Reference [24] suggested four areas of research towards customization, namely 1) the economics of search, 2) cognitive cost approaches, 3) constructed preference approaches, and 4) phenomenological approaches. This article establishes a more holistic approach towards customization.

Customization is particular important for companies delivering products and services which are associated 
with the living style and taste of a person. Reference [16] proposed that joint alliance service customization would cater for a business which pushes dynamic information to individual consumers.

Beside [9] who investigated the alignment of three customization strategies (transaction customization, decision customization, and product customization) with three product types (convenience goods, shopping goods and specialty goods), there are no studies examining the impacts of customizations in an extensive manner. This study attempts to examine customizations involving information searching, transaction arrangement, product design and sales' service on customer satisfaction in an online business. Our integrative framework is discussed in details as follows.

\subsection{Information Customization and Customer Satisfaction}

Information customization signifies the multiple ways in which companies can arrange and organize online information (in terms of display and content) to reflect their customers' preferences [25]. Often, customers are overwhelmed with the plethora of products and services available. With an established customer database, a company would easily keep track the behavior and preference of its customers. Upon the login of a customer, the online store can tailor information content and push to the customer via popup banner and other cues. This would help customers identify their needs and facilitate their decision making in an effective way.

Reference [26] stated customer satisfaction is related to two stimuli-an outcome and a comparison referent. A customer feels satisfied when he/she has greater experience than his/her expectation. In usual, the website of an online store provides the latest information about their products. The comparison referent is based on the experience of visiting these websites. In case a website gives customized information dynamically to individual customers, this will generate greater experience than that in the common referent. Hence, information customization on an online store will induce high customer satisfaction and we propose the following hypothesis:

H1: Information customization has a significant positive impact on customer satisfaction.

\subsection{Transaction Customization and Customer Satisfaction}

Transaction customization refers to different logistic and payment options for customers in handling a transaction and allows customers to complete and to trace a transaction conveniently. Reference [25] hypothesized that transaction inconvenience is a factor contributing to the high abandonment rates of shopping carts in electronic retailing. The frustration that the customers encounter in the online transaction experience with inconvenient electronic shopping carts or processing speed is similar to that of waiting in long lines at a retail store. Ultimately, as [27] explained, customizing the transaction process for customers allows "individuals to complete their transactions more efficiently". The speed of the transaction is also a vital component of transaction customization. Based on the profile of a customer in the customer database, an online store would save the customer's effortfilling in the address and payment details of an order.

Moreover, it is important for customers to decide on the payment and logistic arrangement based on a list of options. The well-known gardening and landscaping website garden.com provides us with an example of transaction customization. On garden.com, shipping arrangements and delivery scheduling are preset according to customer preference in their past transactions. Certainly the customer can modify the preset to some other options if necessary. On the other hand, in nowadays' online business, customers would also trace their sales history and order status online in real time through the website of the online store. We argue that for a company providing convenience for customers in handling and tracing their transactions in terms of payment and logistic arrangement in a more customized way, the higher will be the satisfaction of the customers. Hence, we put forth the following hypothesis:

H2: Transaction customization has a significant positive impact on customer satisfaction.

\subsection{Product Customization and Customer Satisfaction}

Product customization provides a means for customers to specify their products according to a wide variety of options and accessories in specifying a product. It relies on advanced manufacturing using modular design in a product. Product customization is the adaptation of products to the individual tastes and needs of consumers [9]. Involving customers in the process creates a sense of ownership for the customers. When customers design a unique product, they feel a sense of accomplishment (the "I designed it myself" effect) [28]. Buying a ready- 
made product generally provides the customer a lower degree of psychological ownership [29]. Therefore, many companies consider the "I designed it myself" effect and allow customers to design their unique products [2] [30]-[32].

Along with the "I designed it myself" effect, customers are empowered by designing their own products using the interactive platforms provided by online retailers. Companies allow customers to experience the feeling of "having an impact" on the product. By participating in the process, customers' feelings of self-efficacy (a "cando" attitude) and responsibility lead to stronger feelings of ownership [33].

This is consistent with the literature on empowerment in general: when people are allowed to participate actively in decision-making that may influence the final outcome, the decisions become their decisions [34]. In other words, people assume psychological ownership of such decisions because they are partly responsible for the outcome, and this tends to elicit positive feelings of satisfaction [35] [36]. This would bring the happiness and pleasure during the process. Therefore, a highly customized product increases the likelihood of customer satisfaction. This leads to the following hypothesis:

H3: Product customization has a significant positive impact on customer satisfaction.

\subsection{Service Customization and Customer Satisfaction}

Service customization focuses on serving customers preferentially and in different manners. It is a kind of customization because it caters for the unique wants and needs of different customer types by providing them with specific services, social benefits and treatment [37] and is for building, developing and maintaining targeted customer types [23] [38]-[40]. For instance, while VIP members get a complementary gift along with their purchase because of their status, ordinary members will also be happy after receiving an electronic greeting during their birthday month. These tailored services such as personal recognition, discounts, price breaks and extra attention, offer unique value to customers [40] [41]. Service customization would help companies build and stabilize the relationship between different types of customers and the company [42].

Upon the value of customized service, some researchers have suggested that customers typically compare themselves with "similar others" [43]. This need for comparison is pervasive, even though customers make the comparisons unintentionally [44] and without self-awareness [45]. With time, customized service may make customers feel special and entitled to adulation [46]. Numerous researchers have concluded that people feel better when they perceive themselves to be served differently and preferentially [47] [48]. These customized services would be so personalized that would not be applicable to other customers. Such a feeling might enhance the relationship of a customer with the company [49] [50]. Research has confirmed that customized service can be used to establish a good customer relationship [51] [52], which may also lead to customer satisfaction. Hence, we predict the following hypothesis:

H4: Service customization has a significant positive impact on customer satisfaction.

\subsection{Control Variables}

Perceived value is defined as the net benefits customers gain in proportion to their costs, including the amount paid and the related transactional cost [53] [55]. What constitutes value seems to vary widely from one person to another [54] [55]. However, the impact of perceived value on satisfaction cannot be neglected; a considerable amount of research has focused on identifying the impact of perceived value on customer satisfaction [56]-[58]. This study also considers perceived value as an important factor on customer satisfaction.

The backgrounds of users may influence their online shopping behavior. Prior online shopping experience, for example, may be proportionate to satisfaction. Moreover, the education of users sometimes increases with their understanding of online shipping. Different levels of understanding result in different presumptions, influencing user satisfaction. Therefore, it was necessary to control the possible effects of gender, age, prior shopping experience and education on satisfaction. The theoretical framework is shown in Figure 1.

\section{Methodology}

To measure the constructs, we adopted validated items used by other researchers. All of the constructs were assessed using a 7-point scale from 1 (strongly disagree) to 7 (strongly agree). The measurement on customizations of information delivery, transaction handling and product design are adopted from [9]. These constructs 


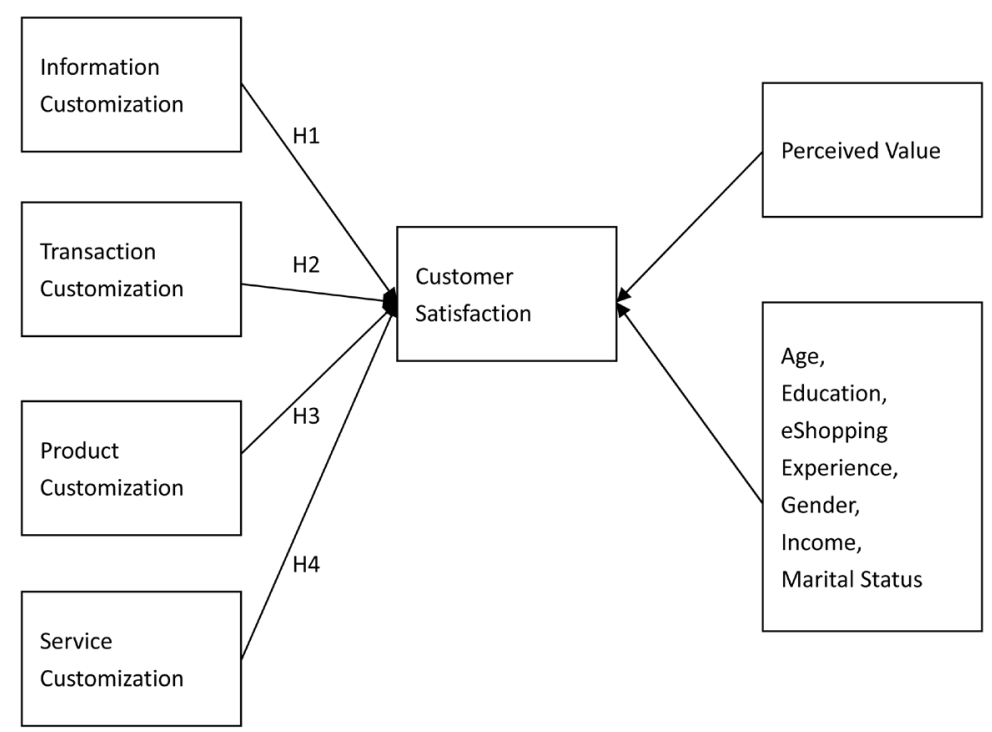

Figure 1. Research model.

were measured through survey statements such as "this online store recommends customized information on products that you may be interested in based on the website's best-selling products"; "this online store allows you to update your shipping, billing, and payment information conveniently"; and "this online store allows you to state your preference on the design of a product". The measurement of service customization is modified based on the concepts from [40] [59]. This construct consists of items such as "this online store serves you in a good way that is unlikely happened in other customers". The construct of satisfaction is assessed by the scale developed by [60] and included items such as "You are satisfied with your decision to purchase from this online store". For the control variables, perceived value is adapted from [61] with items such as "Compared to alternative websites, this online store fairly charges for similar products/services”.

The profile of a respondent was collected at the end of the questionnaire. Membership was coded with ordinary member as 0 and VIP as 1 . Gender was coded with 0 for "female" and 1 for "male", while marital status was coded with 0 for "single" and 1 for "married". Age was coded with 1 for "below 20" and 5 for "36 or above". Similarly, education was coded with 1 for "primary school" and 5 for "postgraduate", while the online shopping experience was coded with 1 for "less than one year" and 5 for "more than four years". Annual income was coded with 1 for "below RMB30,000" (US\$4635) and 7 for “RMB300,001 or over".

A professional translator fluent in both Chinese and English was hired to translate the Chinese version of the survey to English. After the translation process, we verified both the English and Chinese versions to ensure they were of identical meaning before sending them out. The Chinese version was also back-translated to English to ensure both versions have identical meaning. The essential items in the survey are shown in Table 1.

\subsection{Sampling}

We conducted a questionnaire-based survey for an online jewelry company in China on March 2011. This online company was founded by a well-known jewelry manufacturer in the international market with a strong position in the industry. The average amount in each purchase was fallen within a price range of RMB1000-5000 (around US\$150-770). There were totally 4122 active online customers purchasing from this online company till up to March 2011. According to its membership structure, customers who made more than two purchases since the store open in 2008 are promoted to VIP members. Otherwise, they were all ordinary members. Nevertheless, this online company was acquired by an US investor who decided to transform it to some other online business in late 2012. Hence, this online company was close down in November 2012.

The cover page of the online survey stresses on confidentiality in handling the data. To ensure validity in filling the questionnaire, all respondents were reminded to read and answer the survey carefully. To ensure the clarity and understandability, hyperlinks leading to a specific icon or function in the website of the online company were shown along with the questions. In addition, two part-time research assistant were hired to send 
Table 1. Constructs in the framework.

\section{Information Customization (IC)}

IC1 This online store recommends customized information on jewelry products that you may be interested in based on the website's best-selling products.

IC2 This online store recommends customized information on jewelry products that you may be interested in based on the comments of those hot items.

IC3 This online store recommends customized information on jewelry products that you may be interested in based on the items you searched for and purchased on the website.

IC4 This online store recommends customized information on complementary jewelry products that are relevant to you.

\section{Transaction Customization (TC)}

TC1 This online store allows you to review your purchase history in a customized manner.

TC2 This online store allows you to update your shipping, billing, and payment information conveniently.

TC3 This online store allows you to check the status of your order conveniently.

TC4 This online store allows you to save items in a shopping cart for your future return in an easy manner.

TC5 This online store provides a variety of payment and delivery options.

TC6 This online store provides satisfactory payment and delivery options.

\section{Product Customization (PC)}

PC1 This online store allows you to state your preference on the design of a product.

PC2 This online store allows you to specify your product.

PC3 This online store helps you better determine your product requirements.

PC4 This online store actively participates in building the product features that you want.

PC5 This online store actively aids you in identifying which product attributes that fit your needs.

\section{Service Customization (SC)}

PT1 This online store serves you in a good way that is unlikely happened in other customers.

PT2 This online store usually places your request in a high priority.

PT3 This online store provides you with fast service thatis unlikely happened in other customers.

PT4 This online store provides you with good treatment thatis unlikely happened in other customers.

PT5 This online store provides you with special treatment that is unlikely happened in other customers.

\section{Perceived Value (PV)}

PV1 Compared to alternative websites, this online store fairly charges for similar products/services.

PV2 Compared to alternative websites, this online store provides more free services.

PV3 When you compare what you have paid to what you might receive from other competitive website, you think this online store provides you with a good value.

\section{Satisfaction (SA)}

SA1 You are satisfied with your decision to purchase from this online store.

SA2 Your choice to purchase from this online store was a wise one.

SA3 You think you did the right thing in buying from this online store. 
emails, text messages and phone calls to remind its customers to fill in the online questionnaire.

This survey, as with most others, provided an incentive to respondents. Reference [62] stressed that around $57 \%$ of Web-based surveys offer participants an incentive in order to obtain a reasonable response rate. In order to encourage people to respond to our survey, respondents who completed a questionnaire were entered into a lucky draw with a prize of RMB50 in cash. In total, there were 350 prizes.

All 4122 active customers (the ordinary and the VIP members) of the online jewelry company have received an email for the online survey. With the reminders via email and SMS, 1581 responses were received. Among those responses, 198 returns were invalid because of extensive missing values or some special patterns such as same score for all questions. After taking away the 198 invalid questionnaires, there were 1383 valid questionnaires remaining, of which 880 were from ordinary members and 503 from VIP members.

The demographic profiles of the two samples are presented in Table 2. The samples offer a good representation of the population. The respondents who are ordinary members represent around $25 \%$ of the ordinary member pool. Similarly, the respondents who are VIP members represent around $65 \%$ of the VIP pool, with some slight variations. Owing to a good relationship with the company, VIP members have a higher response rate. Of the 1383 valid respondents, $47 \%$ were male and $53 \%$ were female; the ratio of males to females was $0.88: 1$. The respondents were generally well educated, with $75 \%$ having an undergraduate degree in both the ordinary and VIP groups. Almost all respondents reported having online shopping experiences in the past few years. The "younger" groups (with ages of 21 to 30) accounted for more than $70 \%$ of the online purchase from the online jewelry company. More than $60 \%$ of the respondents were single. The annual income of the respondents was concentrated in the lower-income bands. Around $45 \%$ (47\% of the ordinary members and $39 \%$ of the VIP members) of the participants earned below RMB30,000, and 33\% of the respondents were within the annual income range of RMB30,001 - 60,000 (the next-lowest band). Between $1 \%$ and $7 \%$ of the total population fit into the remaining earning bands (RMB100,001 or above).

\subsection{Reliability and Validity Testing}

A factor analysis was carried out on all 26 items in our model on customer satisfaction to reduce the number of items in each construct while maintaining its reliability and discriminant validity. Factors were extracted via the principal component and varimax rotation method. Variables were eliminated if not factorially pure. Table 3 summarizes the factor analysis results, which confirmed that 23 items should remain for the subsequent path analysis.

Those items that did not load strongly on any factor (values below 0.7 ) or those that had cross-loadings were eliminated. A total of three items-PC1, PC2, and TC6 were, therefore, deleted. After further checking with the senior executives of the online jewelry company, the options allow a customer to state their product design (PC1) and to customize their product (PC2) are only available for some expensive products and are not obvious in the website. Hence, the respondents may not have consistent responses to the items PC1 and PC2. On the other hand, TC6 was also dropped due to cross loading with other constructs.

Reliability, as shown in Table 4, refers to the extent to which a construct is free from errors and yields consistent results. Cronbach's alpha was used to measure the internal consistency of the multi-item scales used in this study. As the values of Cronbach's alpha for all constructs were over 0.7, they were deemed reliable. Moreover, we adopt the measurement from constructs used in past studies and the questionnaire was validated by a MIS professor and an expert in customer behavior prior to distribution, the content validity of all the constructs were acceptable.

Table 4 shows the values of the average variance extracted (AVE), which determines the average variance shared between a construct and its measures, of the three antecedent constructs. The AVE of a construct is calculated by the sum of loadings squared divided by the number of items in the construct. The AVE of any construct should be higher than 0.5 for the construct to be reliable.

The correlation matrix of the data set is shown in Table 4. This enables us to examine all potentially overlapping constructs. If the items comprising a construct do not overlap much with other constructs (that is, the AVE of a construct is larger than its squared inter-correlations with other constructs), then the discriminant validity of the construct is assured [63]. Table 4 shows that the diagonal elements (reporting the square root of the variance shared between a construct and its measures) are all higher than the correlations indicating the discriminant validity of all the constructs in this study. 
Table 2. Profile of survey respondents.

\begin{tabular}{|c|c|c|c|c|c|c|c|c|c|}
\hline \multirow{2}{*}{$\begin{array}{c}\text { Type } \\
\text { Demographic } \\
\text { dd } \\
\text { Demographics }\end{array}$} & \multicolumn{4}{|c|}{ Ordinary Members } & \multicolumn{4}{|c|}{ VIP Members } & \multirow{2}{*}{$\begin{array}{c}\text { Tota } \\
\mathbf{N}\end{array}$} \\
\hline & \multicolumn{2}{|c|}{$\begin{array}{c}\text { n1 } \\
\text { Frequency (\%) }\end{array}$} & \multirow[t]{2}{*}{ N1 } & \multirow[t]{2}{*}{$\begin{array}{c}\% \\
\text { (n1/N1) }\end{array}$} & \multicolumn{2}{|c|}{$\begin{array}{c}\text { n2 } \\
\text { Frequency (\%) }\end{array}$} & \multirow[t]{2}{*}{ N2 } & \multirow[t]{2}{*}{$\begin{array}{c}\% \\
\text { (n2/N2) }\end{array}$} & \\
\hline (5) & & & & & & & & & \\
\hline Male & 412 & $47 \%$ & 1592 & $26 \%$ & 237 & $47 \%$ & 377 & $63 \%$ & 1969 \\
\hline Female & 468 & $53 \%$ & 1768 & $26 \%$ & 266 & $53 \%$ & 385 & $69 \%$ & 2153 \\
\hline \multicolumn{10}{|l|}{ Marital Status } \\
\hline Single & 527 & $60 \%$ & 1.984 & $27 \%$ & 293 & $58 \%$ & 442 & $66 \%$ & 2426 \\
\hline Married & 353 & $40 \%$ & 1.376 & $26 \%$ & 210 & $42 \%$ & 320 & $66 \%$ & 1696 \\
\hline \multicolumn{10}{|l|}{ Age (years) } \\
\hline Below 20 & 77 & $9 \%$ & 289 & $27 \%$ & 31 & $6 \%$ & 53 & $58 \%$ & 342 \\
\hline $21-25$ & 397 & $45 \%$ & 1497 & $27 \%$ & 215 & $43 \%$ & 321 & $67 \%$ & 1818 \\
\hline $26-30$ & 254 & $29 \%$ & 958 & $27 \%$ & 170 & $34 \%$ & 260 & $65 \%$ & 1218 \\
\hline $31-35$ & 107 & $12 \%$ & 428 & $25 \%$ & 50 & $10 \%$ & 80 & $63 \%$ & 508 \\
\hline 36 or above & 45 & $5 \%$ & 188 & $24 \%$ & 37 & $8 \%$ & 48 & $77 \%$ & 236 \\
\hline \multicolumn{10}{|l|}{ Education } \\
\hline Primary School & 4 & $0.5 \%$ & 20 & $20 \%$ & 0 & $0 \%$ & 1 & $0 \%$ & 21 \\
\hline Secondary School & 25 & $3 \%$ & 116 & $22 \%$ & 16 & $3 \%$ & 29 & $55 \%$ & 145 \\
\hline Diploma/Higher Diploma & 137 & $16 \%$ & 625 & $22 \%$ & 76 & $15 \%$ & 116 & $66 \%$ & 741 \\
\hline Undergraduate & 662 & $75 \%$ & 2399 & $28 \%$ & 384 & $76 \%$ & 570 & $67 \%$ & 2969 \\
\hline Postgraduate & 52 & $6 \%$ & 200 & $26 \%$ & 27 & $5 \%$ & 46 & $59 \%$ & 246 \\
\hline \multicolumn{10}{|l|}{ e-Shopping Experience } \\
\hline Less than 1 year & 162 & $18 \%$ & 650 & $25 \%$ & 50 & $10 \%$ & 83 & $60 \%$ & 733 \\
\hline $1-2$ years & 205 & $23 \%$ & 825 & $25 \%$ & 126 & $25 \%$ & 192 & $66 \%$ & 1017 \\
\hline 2-3 years & 215 & $24 \%$ & 801 & $27 \%$ & 137 & $27 \%$ & 201 & $68 \%$ & 1002 \\
\hline 3-4 years & 129 & $15 \%$ & 473 & $27 \%$ & 81 & $16 \%$ & 120 & $68 \%$ & 593 \\
\hline Over 4 years & 169 & $19 \%$ & 611 & $28 \%$ & 109 & $22 \%$ & 166 & $66 \%$ & 777 \\
\hline \multicolumn{10}{|l|}{ Annual Income (RMB) } \\
\hline Below 30,000 & 410 & $47 \%$ & 1.620 & $25 \%$ & 194 & $39 \%$ & 315 & $62 \%$ & 1935 \\
\hline $30,001-60,000$ & 291 & $33 \%$ & 1.082 & $27 \%$ & 169 & $34 \%$ & 245 & $69 \%$ & 1327 \\
\hline $60,001-100,000$ & 104 & $12 \%$ & 339 & $31 \%$ & 64 & $13 \%$ & 101 & $63 \%$ & 440 \\
\hline $100,001-150,000$ & 26 & $3 \%$ & 96 & $27 \%$ & 36 & $7 \%$ & 48 & $75 \%$ & 144 \\
\hline $150,001-200,000$ & 19 & $2 \%$ & 83 & $23 \%$ & 20 & $4 \%$ & 23 & $87 \%$ & 106 \\
\hline $200,001-300,000$ & 13 & $1 \%$ & 69 & $19 \%$ & 9 & $2 \%$ & 13 & $69 \%$ & 82 \\
\hline 300,001 or above & 17 & $2 \%$ & 71 & $24 \%$ & 11 & $2 \%$ & 17 & $65 \%$ & 88 \\
\hline
\end{tabular}

Population: N = Total (4122); N1 = Ordinary Members (3360); N2 = VIP Members (762). Sample: N1 = Ordinary Members (880); N2 = VIP Members (503). 
Table 3. Results of factor analysis.

\begin{tabular}{|c|c|c|c|c|c|c|c|c|c|c|c|c|}
\hline \multirow{2}{*}{ Item } & \multicolumn{6}{|c|}{ Ordinary Members } & \multicolumn{6}{|c|}{ VIP Members } \\
\hline & IC & TC & PC & SC & PV & SA & IC & TC & PC & SC & PV & SA \\
\hline IC1 & 0.782 & 0.047 & 0.053 & 0.063 & 0.097 & 0.177 & 0.727 & 0.065 & 0.017 & 0.060 & 0.102 & 0.144 \\
\hline IC2 & 0.749 & 0.162 & 0.179 & 0.096 & 0.007 & 0.114 & 0.717 & 0.035 & 0.121 & 0.075 & 0.032 & 0.031 \\
\hline IC3 & 0.743 & 0.180 & 0.128 & 0.112 & 0.168 & 0.049 & 0.698 & 0.075 & 0.096 & 0.000 & 0.081 & 0.077 \\
\hline IC4 & 0.729 & 0.152 & 0.177 & 0.092 & 0.127 & 0.003 & 0.690 & 0.064 & 0.030 & 0.018 & 0.152 & 0.042 \\
\hline TCI & 0.158 & 0.672 & 0.175 & -0.038 & 0.164 & -0.129 & 0.053 & 0.732 & 0.093 & -0.012 & -0.102 & 0.149 \\
\hline TC2 & 0.126 & 0.694 & 0.057 & 0.099 & -0.098 & 0.192 & 0.145 & 0.669 & 0.076 & 0.141 & -0.203 & 0.209 \\
\hline TC3 & 0.079 & 0.772 & 0.056 & 0.064 & -0.002 & 0.123 & 0.092 & 0.772 & 0.036 & 0.051 & 0.024 & -0.024 \\
\hline TC4 & 0.145 & 0.764 & 0.094 & 0.022 & -0.023 & 0.065 & 0.038 & 0.707 & 0.117 & 0.050 & 0.088 & -0.042 \\
\hline TC5 & 0.044 & 0.705 & 0.199 & 0.069 & 0.168 & -0.129 & -0.029 & 0.631 & 0.159 & 0.011 & 0.247 & -0.121 \\
\hline РC3 & 0.203 & 0.198 & 0.705 & 0.113 & 0.120 & 0.189 & 0.071 & 0.191 & 0.768 & 0.018 & 0.079 & 0.119 \\
\hline PC4 & 0.206 & 0.191 & 0.793 & 0.072 & 0.101 & 0.081 & 0.104 & 0.142 & 0.833 & -0.010 & -0.019 & 0.029 \\
\hline PC5 & 0.131 & 0.156 & 0.778 & 0.139 & 0.126 & 0.165 & 0.102 & 0.084 & 0.795 & 0.003 & 0.099 & 0.116 \\
\hline SC1 & 0.123 & 0.039 & 0.032 & 0.772 & 0.087 & 0.127 & 0.060 & 0.065 & 0.003 & 0.763 & 0.094 & 0.058 \\
\hline SC2 & 0.061 & 0.064 & 0.127 & 0.830 & 0.080 & 0.159 & 0.032 & 0.058 & 0.027 & 0.876 & 0.013 & 0.071 \\
\hline SC3 & 0.100 & 0.080 & 0.068 & 0.864 & 0.126 & 0.130 & -0.002 & 0.035 & 0.025 & 0.894 & 0.043 & 0.086 \\
\hline SC4 & 0.063 & 0.050 & 0.075 & 0.863 & 0.147 & 0.062 & 0.046 & 0.021 & 00.00 & 0.911 & 0.034 & 0.043 \\
\hline SC5 & 0.059 & 0.009 & 0.076 & 0.858 & 0.148 & 0.073 & 0.053 & 0.045 & -0.032 & 0.859 & 0.038 & 0.077 \\
\hline PV1 & 0.170 & 0.008 & 0.097 & 0.161 & 0.718 & 0.261 & 0.171 & -0.002 & 0.056 & 0.057 & 0.730 & 0.338 \\
\hline PV2 & 0.066 & 0.061 & 0.132 & 0.167 & 0.733 & 0.272 & 0.140 & 0.047 & 0.053 & 0.117 & 0.810 & 0.218 \\
\hline PV3 & 0.146 & 0.072 & 0.104 & 0.188 & 0.793 & 0.176 & 0.173 & 0.003 & 0.078 & 0.045 & 0.785 & 0.338 \\
\hline SA1 & 0.198 & 0.068 & 0.157 & 0.211 & 0.338 & 0.703 & 0.106 & 0.060 & 0.076 & 0.122 & 0.272 & 0.788 \\
\hline SA2 & 0.116 & 0.036 & 0.201 & 0.218 & 0.294 & 0.760 & 0.113 & 0.032 & 0.102 & 0.116 & 0.254 & 0.855 \\
\hline SA3 & 0.118 & 0.053 & 0.189 & 0.202 & 0.394 & 0.666 & 0.119 & 0.030 & 0.137 & 0.094 & 0.288 & 0.816 \\
\hline
\end{tabular}

Table 4. Squared correlations, reliability, and average variance extracted.

\begin{tabular}{|c|c|c|c|c|c|c|c|c|c|c|c|c|}
\hline \multirow{2}{*}{ Construct } & \multicolumn{6}{|c|}{ Ordinary Members } & \multicolumn{6}{|c|}{ VIP Members } \\
\hline & 1 & 2 & 3 & 4 & 5 & 6 & 1 & 2 & 3 & 4 & 5 & 6 \\
\hline 1: IC & 0.75 & & & & & & 0.70 & & & & & \\
\hline 2: TC & 0.35 & 0.72 & & & & & 0.19 & 0.71 & & & & \\
\hline 3: PC & 0.44 & 0.41 & 0.76 & & & & 0.23 & 0.31 & 0.80 & & & \\
\hline 4: SC & 0.25 & 0.15 & 0.28 & 0.84 & & & 0.12 & 0.13 & 0.03 & 0.86 & & \\
\hline 5: PV & 0.34 & 0.17 & 0.38 & 0.39 & 0.75 & & 0.33 & 0.08 & 0.20 & 0.16 & 0.77 & \\
\hline 6: SA & 0.37 & 0.18 & 0.46 & 0.43 & 0.66 & 0.71 & 0.28 & 0.13 & 0.25 & 0.22 & 0.59 & 0.82 \\
\hline Reliability & 0.80 & 0.79 & 0.78 & 0.91 & 0.78 & 0.83 & 0.70 & 0.76 & 0.76 & 0.92 & 0.84 & 0.88 \\
\hline AVE & 0.56 & 0.52 & 0.58 & 0.70 & 0.50 & 0.51 & 0.50 & 0.50 & 0.64 & 0.74 & 0.60 & 0.67 \\
\hline
\end{tabular}


We conducted the Harmon one-factor analysis suggested by [64] to check for the presence of common method bias. A factor analysis combining all major variables in the research framework (information customization, production customization, service customization, perceived value and satisfaction) detected no single factor explaining the majority of variance. For ordinary members, single-factor analysis shows $30.5 \%$ of the explained variance, whereas for VIP members, $22.9 \%$ of the explained variance is detected in the single-factor analysis. In addition, results of the structural models showed different degrees of significance for path coefficients. These facts suggest that common method bias is not a serious concern in this study.

We conducted a non-response bias analysis by testing for significant differences between the means of early and those of late respondents, with the late respondents considered as surrogates for non-respondents [65], using t-tests at a 0.05 significance level. We divided all valid samples in half. The first batch included $50 \%$ of the responses collected (440 of the total 880 samples collected for ordinary members; 251 of the total 503 samples collected for VIP members). These responses were compared with the remainder of the responses collected later. Our results indicated no significant difference between the two waves of responses. This suggests that non-response bias is not a concern with this study.

\section{Analysis and Findings}

Judging by the standard deviations of all of the items, the sampled data had enough variations to represent the population (see Table 5). The means of information customization further suggest that ordinary members and VIP members had about the same perception of information customization. This would indicate that both types of customers appreciate the organization and the presentation of information provided by the online jewelry company.

By looking at the mean values of product customization, service customization, perceived value, and satisfaction, we are surprised that ordinary members are more favorable toward the online jewelry company than VIP members. After discussing this finding with senior executives of the online jewelry company, we understood that the focus of this company was on market penetration. Hence much attention has been given to ordinary members especially those who have made their first purchase. Customized information is pushed to them via emails and short message services. There are also specific services—such as educating ordinary members on how to judge the quality of diamonds. Immediate service repairs, flexible customer return and refund policies, are also offered to ordinary members. As a result, ordinary members would be more satisfied than the VIP ones.

Regarding transaction customization, our findings as shown in Table 5 suggests that customers trust services provided by certain well-established third parties. It is because this online jewelry company customizes payment and logistic arrangement according to the services as provided by Alipay and SF Express in China, which are popular payment gateway and parcel carrier respectively. These companies are seen as useful, reliable and trustworthy; therefore, both ordinary and VIP members perceive transaction customization more favorably than information and product customization.

Online companies customize their services to different types of customers according to their marketing tactics. Often, this kind of service is provided only to VIP members because speeding up the normal production time from weeks to a few days involves various operational arrangements and resources reallocations. Due to recent severe competition in China, many online stores in China tend to treat their potential and existing customers

Table 5. Descriptive statistics and reliability of constructs.

\begin{tabular}{cccc}
\hline \multirow{2}{*}{ Construct } & Ordinary Members & VIP Members & \multicolumn{1}{c}{ Differences } \\
\cline { 2 - 4 } & Mean (S.D.) & Mean (S.D.) & Mean (Ordinary Members)_Mean (VIP Members) \\
\hline Information Customization & $5.79(0.72)$ & $5.80(0.70)$ & -0.01 \\
Transaction Customization (5) & $6.21(0.68)$ & $6.35(0.64)$ & $-0.14^{* * *}$ \\
Product Customization & $5.85(0.80)$ & $5.72(0.83)$ & $0.13^{* *}$ \\
Service Customization & $5.45(1.03)$ & $5.23(1.19)$ & $0.22^{* *}$ \\
Perceived Value & $5.51(0.83)$ & $5.36(0.93)$ & $0.15^{* *}$ \\
Satisfaction & $5.64(0.82)$ & $5.51(0.91)$ & $0.13^{* *}$ \\
\hline
\end{tabular}


preferentially for market expansion. For example, an ordinary member (or a potential customer) may inquire about an expensive diamond ring in the online jewelry store. Due to the potential value of this purchase which indicates the importance of the customer, a jewelry consultant will contact the customer directly, either through email or over the phone. With a specific monetary guarantee, such as a credit card deposit, the diamond ring will be delivered to the customer for inspection. If the customer decides not to purchase, he/she need to return the diamond without any charge by courier within a specified period.

To test our hypotheses, we used structural equation modeling from AMOS [66] [67]. This provides goodness-of-fit measures for the estimated models that access absolute-fit measures, such as chi-square statistics goodness-of-fit (GFI), and root mean square residual (RMSEA) and incremental fit measures, such as degree of freedom and the adjusted goodness-of-fit index (AGFI), in addition to parsimonious-fit measures such as the comparative fit index (CFI). As shown in Table 6, all indices of both structural models meet the terms of [68] combinational rule, providing evidence of a good model fit.

Figure 2 illustrates our analyzed results for the ordinary and VIP members. The findings from both structural equation models indicate that annual income, e-shopping experience, and age do not have a significant effect on satisfaction, while marital status shows a negative coefficient with $\mathrm{p}<0.05$, indicating that married customers are less satisfied than single ones within the ordinary member group. Moreover, gender has positive coefficients with $\mathrm{p}<0.05$ and $\mathrm{p}<0.1$ for ordinary and VIP members, respectively, indicating that females are less satisfied than males within both customer groups.

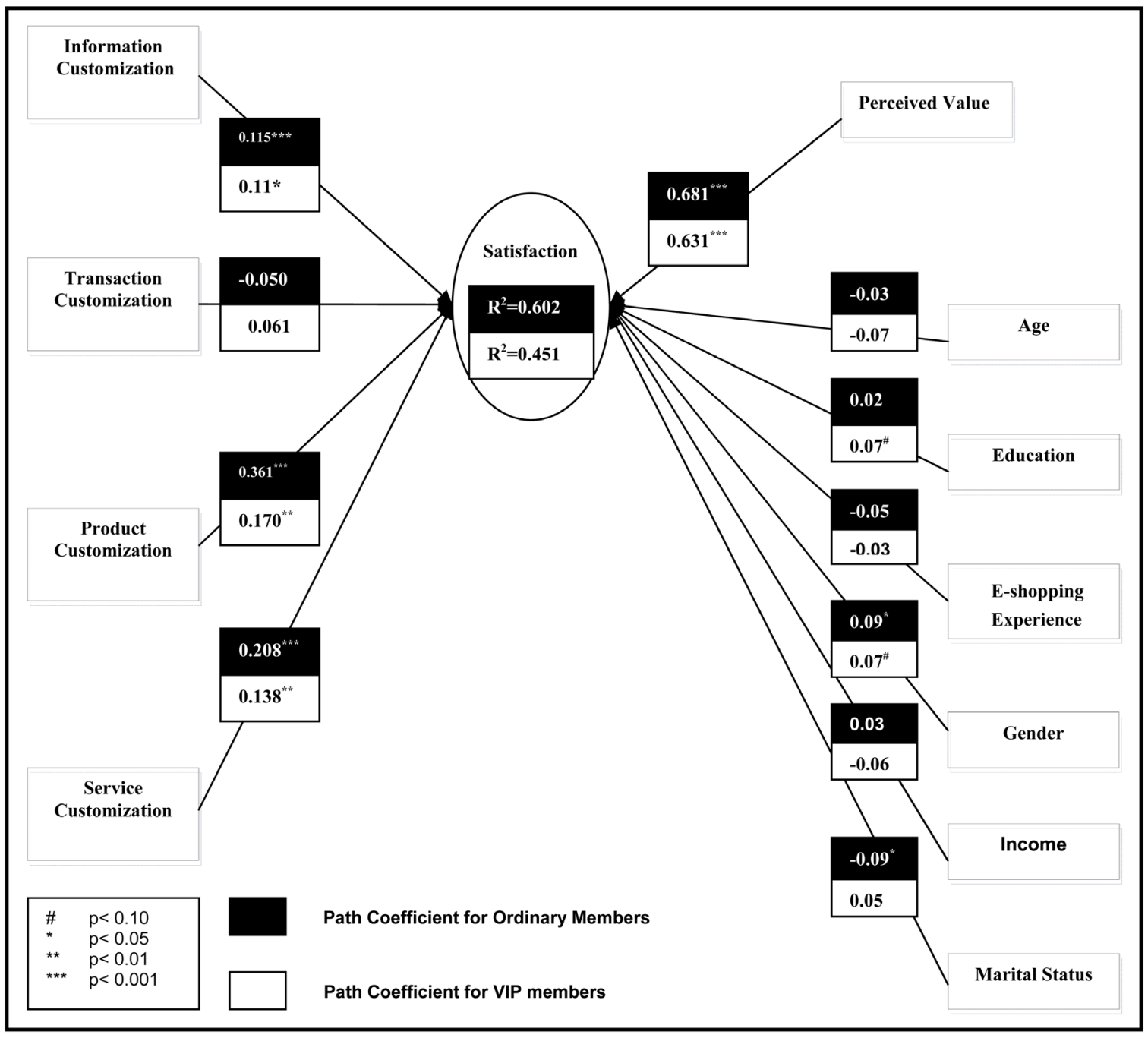

Figure 2. Structural models (Ordinary vs. VIP members). 
Table 6. Structural model fit-multi-group analysis.

\begin{tabular}{ccc}
\hline Fit indices & Both types of customers (Ordinary and VIP members) & Desired levels \\
\hline$\chi^{2} / \mathrm{df}$ & 2.458 & $<3.00$ \\
CFI & 0.935 & $>0.90$ \\
RMSEA & 0.032 & $<0.08$ \\
GFI & 0.908 & $>0.90$ \\
AGFI & 0.890 & $>0.80$ \\
IFI & 0.938 & $>0.90$ \\
\hline
\end{tabular}

From our analysis as shown in Figure 2, information customization, product customization and service customization all have a significant impact on satisfaction for both types of customers. Product customization has the strongest positive impact on satisfaction for ordinary and VIP members. Results showed that H1, H3, and H4 are supported in both samples. Nevertheless, H2, which states that transaction customization has a significant impact on satisfaction, is not supported for either type of customers. In addition, the explained variances (r-squared) of satisfaction for ordinary and VIP members are 0.60 and 0.43 respectively.

\section{Discussion}

The results ( $\beta=0.115^{* * *}$ for ordinary members and $\beta=0.110^{*}$ for VIP members) suggest that information customization has a positive impact on satisfaction for both types of customers. Customers are pleased with latest customized information on products and promotions while they login the online jewelry company. These product information and promotions are highlighted by various headings and sidebars. Given a variety of choice without much disturbance, customers visiting this website can have much leisure in comparing different products on their interests. This provides a better environment as compared with the traditional jewelry store. Shopping online for inexpensive items would normally demand less for product information than that of expensive items. As customers (both ordinary and VIP members) are pleased with the customized information provided by the company, it is reasonable that they are both satisfied.

The results show that transaction customization, unlike information customization, has no impact on satisfaction for either ordinary members or VIP members. The transaction arrangement may be less important when compared with information and product customization which are more related to the decision for making a purchase especially on those personalized products like jewelry. Moreover, as from the descriptive statistics, we suspect that the customized services as provided from the third party logistic and payment providers which are trustworthy. Hence it is also reasonable that these customized services do not have impacts on satisfaction with the company.

Our findings show that product customization affects the satisfaction of both types of members. This is reflected in the path coefficients of $0.361^{* * *}$ and $0.170^{* *}$ for product customization, regarding satisfaction of ordinary and VIP members, respectively. Though ordinary members purchase in small amounts on jewelries upon their first time from an online store, they do want to have their own customized products. For instance, the following illustrates how a customer customizes a diamond ring. With an interactive interface, a customer would select a diamond according to its shape (round, heart, square, and oval) and quality (color, clarity, cut, and carat weight). Then the customer can design their own diamond ring from different combinations of ring mountings using different gold tone ( $9 \mathrm{~K}, 14 \mathrm{~K}, 18 \mathrm{~K}, 24 \mathrm{~K}$, and platinum). They can also engrave a short message at the rim of the ring. Such options are appreciated by both ordinary and VIP members because they can then design their final products based on their own style and preference. It is because buying luxury products like jewelry usually have high expectation on the product that fits the taste and style of a customer. Hence, product customization is very essential leading to customer satisfaction.

From our analyses, service customization has a positive impact on the satisfaction level for ordinary members $\left(\beta=0.208^{* * *}\right)$ and for VIP members $\left(\beta=0.138^{*}\right)$. In this online jewelry company, members usually received customized treatments according to their needs and requests. This arrangement proves that service customization is effective for inducing customer satisfaction. 
With respect to the control variable, perceived value has also significant impact on customer satisfaction for ordinary members $\left(0.681^{* * *}\right)$ and VIP members $\left(0.631^{* * *}\right)$. In China, online shoppers are very concerned about "value for money". And they always compare prices of similar products and services from different online stores. Once they achieve searching and acquiring a product with a reasonable price, they will feel satisfied.

In terms of contributions, this study empirically supports the theoretical model for customization strategies for an online business. The current research confirms the impact of the four customization perspectives on satisfaction. The findings suggest that customers need information from a Website. Product customization, however, has most impacts on satisfaction. In addition, service customization, which would influence the customer relationship, is also important to customers. This study represents an important step toward developing a theoretical understanding of the impact of customization strategy. The results also provide insights for online stores to devise more effective buyer-centric strategies.

\section{Limitations and Conclusion}

As it is the case with all empirical research, this investigation has several limitations. The cross-sectional research design dictated that all measurement items were collected. This research method may not fully capture the dynamics of the influence on online business. This constraint limits the extent to which causality can be inferred. To address the above issues, future research should consider employing multiple methods and longitudinal research designs. A longitudinal study combining qualitative and quantitative data would enable a processoriented perspective that cannot be achieved using a variance-based approach, such as the one employed here.

In addition, our results may not be able to generalize to those in dissimilar institutional contexts. The online jewelry business in China is still emerging, and is on luxury product stressing on personal taste and style. Extending our findings to other online businesses such as 3C sites and apparel business, or business operating in different institutional and cultural environments should be taken in cautions.

In sum, this study investigates the impacts of customizations on customer satisfaction in an online jewelry business and observes the differences between the two groups of customers (ordinary and VIP members). Our framework is testified using the online jewelry store in China. It is an expanding market and gaining widespread popularity among high-income earners. Our findings confirm that information customization, product customization and service customization have significant impacts. Nevertheless, transaction customization does not contribute much to customer satisfaction. It is due to the fact that the online jewelry company mainly relies on some renowned third party logistic and payment service providers for handling a transaction. Moreover, service customization, which would strengthen the customer relationship, appears to be an effective means for online luxury market in China. Our findings also show differences between ordinary and VIP members. Online stores should consider how their platforms would facilitate different types of members in these four perspectives.

\section{References}

[1] Syam, N.B., Ruan, R. and Hess, J.D. (2005) Customized Products: A Competitive Analysis. Marketing Science, 24, 569-584. http://dx.doi.org/10.1287/mksc.1050.0128

[2] Dellaert, B.G.C. and Stremersch, S. (2005) Marketing Mass-Customized Products: Striking a Balance between Utility and Complexity. Journal of Marketing Research, 42, 219-227. http://dx.doi.org/10.1509/jmkr.42.2.219.62293

[3] Gilmore, J.H. and Pine, J.B. (2000) Markets of One: Creation Customer-Unique Value through Mass Customization. Harvard Business School, Cambridge.

[4] Volling, T. and Spengler, T.S. (2011) Modeling and Simulation of Order-Driven Planning Policies in Build-to-Order Automobile Production. International Journal of Production Economics, 131, 183-193. http://dx.doi.org/10.1016/j.ijpe.2011.01.008

[5] Brabazon, P.G., MacCarthy, B., Woodcock, A. and Hawkins, R.W. (2010) Mass Customization in the Automotive Industry: Comparing Interdealer Trading and Reconfiguration Flexibilities in Order Fulfillment. Production and Operations Management, 19, 489-502. http://dx.doi.org/10.1111/j.1937-5956.2010.01132.x

[6] Palmatier, R.W., Dant, R.P., Grewal, D. and Evans, K.R. (2006) Factors Influencing the Effectiveness of Relationship Marketing: A Meta-Analysis. Journal of Marketing, 70, 136-153. http://dx.doi.org/10.1509/jmkg.70.4.136

[7] Darley, W., Blankson, C. and Luethge, D. (2010) Toward an Integrated Framework for Online Consumer Behavior and Decision Making Process: A Review. Psychology \& Marketing, 27, 94-116. http://dx.doi.org/10.1002/mar.20322

[8] Fornell, C., Rust, R. and Dekimpe, M.G. (2010) The Impact of Spending Growth. Journal of Marketing Research, 47, 
28-35. http://dx.doi.org/10.1509/jmkr.47.1.28

[9] Thirumalai, S. and Sinha, K.K. (2009) Customization Strategies in Electronic Retailing: Implications of Customer Purchase Behavior. Decision Sciences, 40, 5-36. http://dx.doi.org/10.1111/j.1540-5915.2008.00222.x

[10] Thirumalai, S. and Sinha, K.K. (2011) Customization of the Online Purchase Process in Electronic Retailing and Customer Satisfaction: An Online Field Study. Journal of Operations Management, 29, 477-487. http://dx.doi.org/10.1016/j.jom.2010.11.009

[11] Maes, P., Guttman, R.H. and Moukas, A.G. (1999) Agents That Buy and Sell. Communications of the ACM, 42, 81-87. http://dx.doi.org/10.1145/295685.295716

[12] Duray, R., Ward, P.T., Milligan, G.W. and Berry, W.L. (2000) Approaches to Mass Customization: Configurations and Empirical Validation. Journal of Operations Management, 18, 605-625.

[13] Berger, C. and Piller, F. (2003) Customers as Co-Designers: The mi Adidas Mass Customization Strategy. IEE Manufacturing Engineer, 82, 42-46.

[14] Bendapudi, N. and Leone, R.P. (2003) Psychological Implications of Customer Participation in Co-Production. Journal of Marketing, 67, 14-28. http://dx.doi.org/10.1509/jmkg.67.1.14.18592

[15] Simonson, I. (2005) Determinants of Customers’ Responses to Customized Offers: Conceptual Framework and Research Propositions. Journal of Marketing, 69, 32-45. http://dx.doi.org/10.1509/jmkg.69.1.32.55512

[16] Helm, G.R. and Sinha, K.K. (2001) A Product-Process Matrix for Electronic B2C Operations: Implications for the Delivery of Customer Value. Journal of Service Research, 3, 286-299.

http://dx.doi.org/10.1177/109467050134002

[17] Cho, H. and Wang, Y. (2010) Cultural Comparison for the Acceptance of Online Apparel Customization. Journal of Consumer Marketing, 27, 550-557. http://dx.doi.org/10.1108/07363761011078299

[18] Gilmore, J.H. and Pine, J. (1997) The Four Faces of Mass Customization. Harvard Business Review, 75, 91-101.

[19] Lampel, J. and Mintzberg, H. (1996) Customizing Customization. Sloan Management Review, 38, 21-30.

[20] Lee, H.H. and Chang, E. (2011) Consumer Attitudes toward Online Mass Customization: An Application of Extended Technology Acceptance Model. Journal of Computer-Mediated Communication, 16, 171-200. http://dx.doi.org/10.1111/j.1083-6101.2010.01530.x

[21] Wind, J. and Rangaswamy, A. (2001) Customization: The Next Revolution in Mass Customization. Journal of Interactive Marketing, 15, 13-32.

[22] Zipkin, P. (2001) The Limits of Mass Customization. MIT Sloan Management Review, 42, 81-87.

[23] Miceli, G., Ricotta, F. and Costabile, M. (2007) Customizing Customization: A Conceptual Framework for Interactive Personalization. Journal of Interactive Marketing, 21, 6-25. http://dx.doi.org/10.1002/dir.20076

[24] Bellman, S., Johnson, E.J., Lohse, G.L. and Mandel, N. (2006) Designing Marketplaces of the Artificial with Consumers in Mind: Four Approaches to Understanding Consumer Behavior in Electronic Environments. Journal of Interactive Marketing, 20, 21-33. http://dx.doi.org/10.1002/dir.20053

[25] Berry, L.L., Seiders, K. and Grewal, D. (2002) Understanding Service Convenience. Journal of Marketing, 66, 1-17. http://dx.doi.org/10.1509/jmkg.66.3.1.18505

[26] Oliver, R.L. (1997) Satisfaction: A Behavioral Perspective on the Consumer. McGraw-Hill, New York.

[27] Srinivasan, S.S., Andersona, R. and Ponnavolub, K. (2002) Customer Loyalty in E-Commerce: An Exploration of Its Antecedents and Consequences. Journal of Retailing, 78, 41-50. http://dx.doi.org/10.1016/S0022-4359(01)00065-3

[28] Franke, N., Schreier, M. and Kaiser, U. (2010) The "I Designed It Myself” Effect in Mass Customization. Management Science, 56, 125-140. http://dx.doi.org/10.1287/mnsc.1090.1077

[29] Pierce, J.L., Kostova, T. and Dirks, K.T. (2002) The State of Psychological Ownership: Integrating and Extending a Century of Research. Review of General Psychology, 7, 84-107. http://dx.doi.org/10.1037/1089-2680.7.1.84

[30] Franke, N. and Piller, T.P. (2004) Value Creation by Toolkits for User Innovation and Design: The Case of the Watch Market. Journal of Product Innovation Management, 21, 401-415. http://dx.doi.org/10.1111/j.0737-6782.2004.00094.x

[31] Randall, T., Terwiesch, C. and Ulrich, K. (2007) Research Note-User Design of Customized Products. Marketing Science, 26, 268-280. http://dx.doi.org/10.1287/mksc.1050.0116

[32] Chen, J.W., Doraszelski, U. and Harrington Jr., J.E. (2009) Avoiding Market Dominance: Product Compatibility in Market with Network Effects. The RAND Journal of Economics, 40, 455-485.

http://dx.doi.org/10.1111/j.1756-2171.2009.00073.x

[33] Pierce, J.L., Kostova, T. and Dirks, K.T. (2001) Toward a Theory of Psychological Ownership in Organizations. Aca- 
demy of Management Review, 26, 298-310. http://dx.doi.org/10.2307/259124

[34] Hunton, J.E. (1996) Involving Information System Users in Defining System Requirements: The Influence of Procedural Justice Perceptions on User Attitudes and Performance. Decision Sciences, 27, 647-671. http://dx.doi.org/10.1111/j.1540-5915.1996.tb01830.x

[35] Barki, H. and Hartwick, J. (1994) Measuring User Participation, User Involvement, and User Attitude. MIS Quarterly, 18, 59-79. http://dx.doi.org/10.2307/249610

[36] Hui, M. and Bateson, J.E.G. (1991) Perceived Control and the Effects of Crowding and Consumer Choice on the Service Experience. Journal of Consumer Research, 18, 174-184. http://dx.doi.org/10.1086/209250

[37] Tam, K.Y. and Ho, S.Y. (2005) Web Personalization as a Persuasion Strategy: An Elaboration Likelihood Model Perspective. Information Systems Research, 16, 271-291. http://dx.doi.org/10.1287/isre.1050.0058

[38] Morgan, R.M. and Hunt, S.D. (1994) The Commitment-Trust Theory of Relationship Marketing. Journal of Marketing, 58, 20-38. http://dx.doi.org/10.2307/1252308

[39] Hennig-Thurau, T., Gwinner, K.P. and Gremler, D.D. (2002) Understanding Relationship Marketing Outcomes: An Integration of Relational Benefits and Relationship Quality. Journal of Service Research, 4, 230-247. http://dx.doi.org/10.1177/1094670502004003006

[40] Gwinner, K.P., Gremler, D.D. and Bitner, M.J. (1998) Relational Benefits in Services Industries: The Customers’ Perspective. Journal of the Academy of Marketing Science, 26, 101-114. http://dx.doi.org/10.1177/0092070398262002

[41] Gremler, D.D. and Brown, S.W. (1997) Towards a Conceptual Model of Service Loyalty. Marketing Theory and Applications AMA Winter Educators' Conference, MCB UP Ltd., Chicago, 218-219.

[42] Dellaert, B.G.C. and Dabholkar, P.A. (2009) Increasing the Attractiveness of Mass Customization: The Role of Complementary Online Services and Range of Options. International Journal of Electronic Commerce, 13, 43-70. http://dx.doi.org/10.2753/JEC1086-4415130302

[43] Xia, L., Monroe, K.B. and Cox, J.L. (2004) The Price Is Unfair! A Conceptual Framework of Price Fairness Perceptions. Journal of Marketing, 68, 1-15. http://dx.doi.org/10.1509/jmkg.68.4.1.42733

[44] Gilbert, D.T., Giesler, R.B. and Morris, K.A. (1995) When Comparisons Arise. Journal of Personality and Social Psychology, 69, 227-236. http://dx.doi.org/10.1037/0022-3514.69.2.227

[45] Stapel, D.A. and Blanton, H. (2004) From Seeing to Being: Subliminal Social Comparisons Affect Implicit and Explicit Self-Evaluations. Journal of Personality and Social Psychology, 87, 468-481.

[46] Boyd, H.C. and Helms, J.E. (2005) Consumer Entitlement Theory and Measurement. Psychology and Marketing, 22, 271-286. http://dx.doi.org/10.1002/mar.20058

[47] Giordano, C., Wood, J.V. and Michela, J.L. (2000) Depressive Personality Styles, Dysphasia, and Social Comparisons in Everyday Life. Journal of Personality and Social Psychology, 9, 438-451. http://dx.doi.org/10.1037/0022-3514.79.3.438

[48] Locke, K.D. and Nekich, J.C. (2000) Agency and Communion in Naturalistic Social Comparison. Personality and Social Psychology Bulletin, 26, 864-874. http://dx.doi.org/10.1177/0146167200269011

[49] Klemperer, P. (1987) Markets with Consumer Switching Costs. The Quarterly Journal of Economics, 102, $375-394$. http://dx.doi.org/10.2307/1885068

[50] Wernerfelt, B. (1985) Brand Loyalty and User Skills. Journal of Economic Behavior and Organization, 6, $381-385$. http://dx.doi.org/10.1016/0167-2681(85)90005-8

[51] Crosby, L.A. (1991) Building and Maintaining Quality in the Service Relationship. In: Brown, S.W., Gummesson, E., Edvardsson, B., Gustavsson, B. and Lexington, B., Eds., Service Quality: Multidisciplinary and Multinational Perspectives, Lexington Books, Lexington, 269-287.

[52] Berry, L.L. (1983) Relationship Marketing. In: Berry, L.L., Shostack, G.L. and Upala, G.D., Eds., Emerging Perspectives on Services Marketing, American Marketing Association, Chicago, 25-80.

[53] Woodruff, R.B. (1997) Customer Value: The Next Source of Competitive Advantage. Journal of the Academy of Marketing Science, 25, 139-153. http://dx.doi.org/10.1007/BF02894350

[54] Holbrook, M.B. (1994) The Nature of Customer's Value: An Axiology of Service in Consumption Experience. In: Rust, R.T. and Oliver, R.L., Eds., Service Quality: New Directions in Theory and Practice, Sage, Thousand Oaks, 21-71. http://dx.doi.org/10.4135/9781452229102.n2

[55] Zeithaml, V.A. (1988) Consumer Perceptions of Price, Quality, and Value: A Means-End Model and Synthesis of Evidence. Journal of Marketing, 52, 2-22. http://dx.doi.org/10.2307/1251446

[56] Anderson, E.W., Fornell, C. and Lehmann, D.R. (1994) Customer Satisfaction, Market Share and Profitability: Find- 
ings from Sweden. Journal of Marketing, 58, 53-66. http://dx.doi.org/10.2307/1252310

[57] Ravald, A. and Grönroos, C. (1996) The Value Concept and Relationship Marketing. European Journal of Marketing, 30, 19-30. http://dx.doi.org/10.1108/03090569610106626

[58] Bolton, R.N. and Drew, J.H. (1991) A Multistage Model of Customers’ Assessment of Service Quality and Value. Journal of Consumer Research, 54, 69-82.

[59] Skaggs, B.C. and Youndt, M. (2004) Strategic Positioning, Human Capital, and Performance in Service Organizations: A Customer Interaction Approach. Strategic Management Journal, 25, 85-99. http://dx.doi.org/10.1002/smj.365

[60] Oliver, R.L. (1980) A Cognitive Model of the Antecedents and Consequences of Satisfaction Decisions. Journal of Marketing Research, 17, 460-469. http://dx.doi.org/10.2307/3150499

[61] Levesque, T. and McDougall, G.H.G. (1996) Determinants of Customer Satisfaction in Retail Banking. International Journal of Bank Marketing, 14, 12-20. http://dx.doi.org/10.1108/02652329610151340

[62] Ray, N., Griggs, K. and Tabor, S. (2001) Web Based Survey Research Workshop, WDSI.

[63] Fornell, C. and Larcker, D.F. (1981) Evaluating Structural Equation Models with Unobservable Variables and Measurement Error. Journal of Marketing Research, 18, 39-50. http://dx.doi.org/10.2307/3151312

[64] Podsakoff, P.M. and Organ, D.W. (1986) Self-Reports in Organizational Research: Problems and Prospects. Journal of Management, 12, 531-544. http://dx.doi.org/10.1177/014920638601200408

[65] Armstrong, J.S. and Overton, T.S. (1977) Estimating Nonresponse Bias in Mail Surveys. Journal of Marketing Research, 14, 396-402. http://dx.doi.org/10.2307/3150783

[66] Joreskog, K.G. and Sorbom, D. (1986) PRELIS: A Program for Multivariate Data Screening and Data Summarization. Scientific Software, Mooresville.

[67] Hair, J., Anderson, R., Tatham, R. and Black, W. (1998) Multivariate Data Analysis. 5th Edition, Prentice Hall, Upper Saddle River.

[68] Hu, L.T. and Bentler, P.M. (1999) Cutoff Criteria for Fit Indexes in Covariance Structure Analysis: Conventional Criteria versus New Alternatives. Structural Equation Modeling, 6, 1-55. http://dx.doi.org/10.1080/10705519909540118 